\title{
Factors associated with iron deficiency in pregnant women seen at a public prenatal care service
}

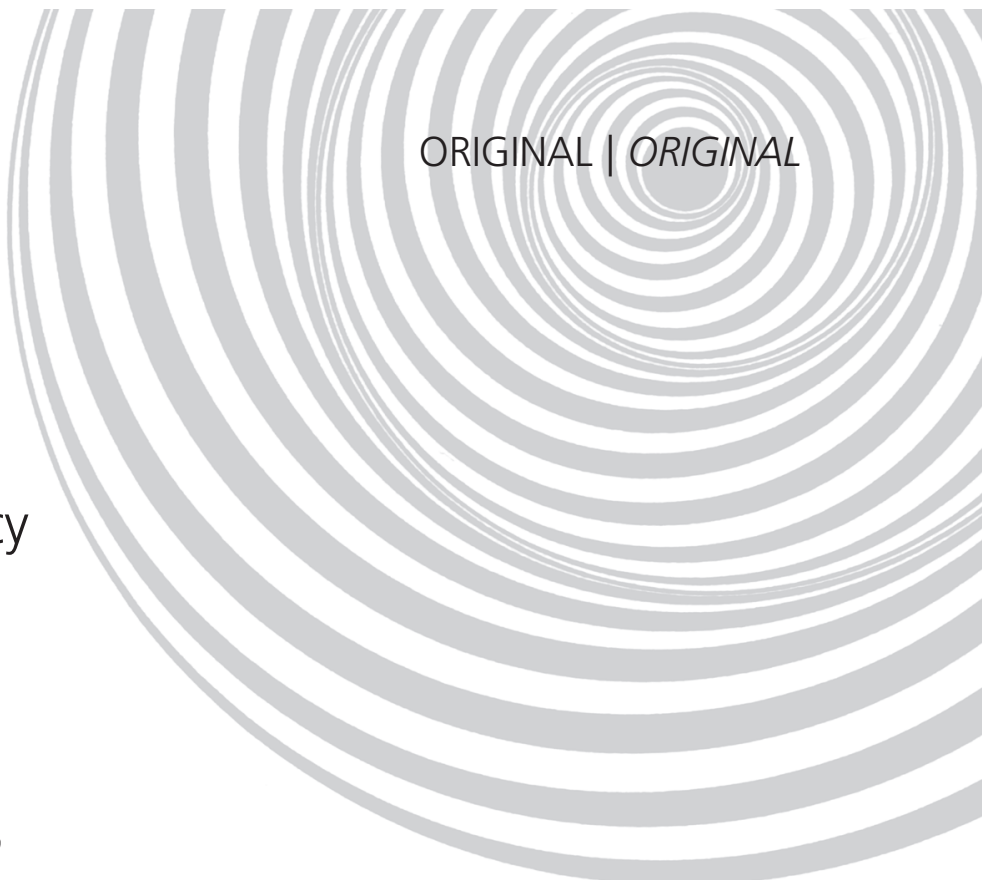

Fatores associados à deficiência de ferro

em gestantes atendidas em serviço

público de pré-natal

Rosângela Maria Souza de CAMARGO'

Rosângela Alves PEREIRA²

Edna Massae YOKOO${ }^{3}$

Janine SCHIRMER ${ }^{4}$

A B S T R A C T

\section{Objective}

This study aimed to determine the frequency of iron deficiency and its association with socioeconomic, obstetric, and nutritional factors in pregnant women.

\section{Methods}

This cross-sectional study included women on the second trimester of pregnancy seen at a public prenatal care facility of Cuiabá, Mato Grosso, Brazil from May 2008 to May 2009. Socioeconomic, nutritional, and obstetric data were compared with markers of iron stores.

\section{Results}

During the study period, 146 pregnant women met the inclusion criteria. The frequency of anemia characterized by abnormal hemoglobin level, hematocrit, and mean corpuscular volume varied from $3 \%$ to $5 \%$. However, $11 \%$ of the women had high transferrin levels and $39 \%$ had low ferritin levels. Before pregnancy, $21 \%$ of the women were underweight and $29 \%$ were overweight or obese. During pregnancy, the percentage of overweight or obese women rose to $40 \%$. History of miscarriages, higher gestational age, and excess weight before pregnancy were associated with markers of iron stores at abnormal levels. Consumption of specific food groups was not associated with abnormal marker levels.

${ }^{1}$ Universidade Federal do Mato Grosso, Faculdade de Nutrição, Departamento de Alimentos Nutrição. Av. Fernando Correa da Costa, 2367, Boa Esperança, Campus Universitário, 78060-900, Cuiabá, MG, Brasil. Correspondência para/Correspondence to: RMS CAMARGO. E-mail: <rosanms@terra.com.br>.

2 Universidade Federal do Rio de Janeiro, Instituto de Nutrição Josué de Castro. Rio de Janeiro, RJ, Brasil.

3 Universidade Federal Fluminense, Instituto de Saúde da Comunidade. Niterói, RJ, Brasil.

${ }^{4}$ Universidade Federal de São Paulo, Escola Paulista de Enfermagem. São Paulo, SP, Brasil. 
456 | RMS CAMARGO et al.

\section{Conclusion}

Serum ferritin was the most sensitive indicator of iron deficiency. Excess weight and anemia were concomitant.

Indexing terms: Anemia. Ferritins. Food intake. Iron deficiency. Nutritional status. Pregnancy.

\section{R E S U M O}

\section{Objetivo}

Verificar a frequência de deficiência de ferro e sua associação com fatores socioeconômicos, obstétricos e nutricionais em gestantes.

\section{Métodos}

Estudo transversal desenvolvido com gestantes no segundo trimestre da gestação atendidas em ambulatório de pré-natal da rede pública de Cuiabá, Mato Grosso, entre maio de 2008 e maio de 2009. Dados sobre as características socioeconômicas, nutricionais e obstétricas foram relacionados aos indicadores de reservas de ferro.

\section{Resultados}

No período do estudo, 146 gestantes atenderam aos critérios de inclusão na pesquisa. A frequência de anemia variou de 3\% a 5\%, considerando-se os valores para hemoglobina, hematócrito e volume corpuscular médio. Entretanto, a frequência de alterações nos indicadores de reservas de ferro variou de $11 \%$ para transferrina a $39 \%$ para ferritina. No período pré-gestacional, $21 \%$ das gestantes apresentavam baixo peso e $29 \%$ excesso de peso (sobrepeso ou obesidade); no período gestacional, a ocorrência de excesso de peso aumentou (40\%). Histórico de aborto, idade gestacional e status de peso pré-gestacional se associaram às alterações nos indicadores de reservas de ferro. Não se observou associação entre o consumo de grupos de alimentos e alterações nos indicadores de reservas de ferro.

\section{Conclusão}

O indicador mais sensivel na identificação da deficiência de ferro foi a ferritina sérica. Observou-se concomitância de excesso de peso e deficiência de ferro.

Termos de indexação: Anemia. Ferritina. Consumo Alimentar. Deficiência de Ferro. Estado Nutricional. Gravidez.

\section{NTROD U CTION}

According to the World Health Organization', half of all pregnant women develop anemia, which is characterized by a hemoglobin level lower than $11 \mathrm{~g} / \mathrm{dL}$. The mean prevalence of anemia in pregnant women from developed and developing countries is $18 \%$ and $56 \%{ }^{2}$, respectively, but it may be as high as $75 \%$ in India ${ }^{3}$.

In Brazil, anemia is the most common nutritional problem, especially in children under two years of age and in pregnant women, with prevalences of $50 \%$ and $35 \%$, respectively ${ }^{2}$. The National Survey on the Demography and Health of Children and Women reported that 30\% of the women of childbearing age are anemic and that there are no national studies with consistent data about the occurrence of anemia in pregnant women 4 . In a review study, Côrtes et al. ${ }^{5}$ reported that the prevalence of anemia in Brazilian women on the second trimester of pregnancy varies from $9 \%$ to $44 \%$.

The primary causes of anemia during pregnancy are inadequate intake of dietary iron ${ }^{6}$, greater fetal demand, and increased blood volume during pregnancy ${ }^{7}$. Although iron absorption is high during pregnancy, the amount of dietary iron absorbed and mobilization of the iron stores are not enough to meet the demand ${ }^{8}$. However, the etiology of anemia during pregnancy in developing countries also includes factors such as low socioeconomic and education levels ${ }^{4}$, and high parity ${ }^{6}$.

Iron deficiency is associated with high morbidity and mortality rates. Furthermore, 
anemia impairs mental development and the ability to work and study productively ${ }^{9}$. During pregnancy, anemia is associated with a higher rate of mother/fetus morbidity and mortality, and the most common complications are early labor, low birth weight, preeclampsia, and higher risk of miscarriage ${ }^{10}$.

The objective of this study was to investigate whether socioeconomic, obstetric and nutritional factors are associated with anemia/iron deficiency in pregnant women.

\section{METHODS}

This cross-sectional study was done at the outpatient clinic of the Hospital Universitário Júlio Muller (HUJM) of the Universidade Federal do Mato Grosso (UFMT), Cuiabá, Mato Grosso, Brazil, which is a reference hospital for low- and highrisk pregnancies.

The study was approved by the Research Ethics Committee (Comitê de Ética e Pesquisa (EP) of the Universidade Federal de São Paulo (Unifesp) under protocol number 1468/CEP/ Unifesp/2007 and of HUJM under protocol number 384/CEP/HUJM/2007. All participants signed a free and informed consent form before they entered the study.

\section{Study design and population}

The study population consisted of pregnant women seen at the HUJM prenatal care outpatient clinic. Women aged 19 to 49 years on the second trimester of their first pregnancy seen between May 2008 and May 2009 were eligible. Women with the following pre-pregnancy conditions were excluded: kidney, liver, heart, pulmonary, and endocrine diseases; infectious diseases, such as tuberculosis and Acquired Immunodeficiency Syndrome (AIDS); high blood pressure; diabetes Mellitus; and obstetric diseases, such as preeclampsia, placental abruption, and bleeding. The gestational ages were collected from ultrasound reports in the participants « medical records. The second trimester of pregnancy was defined as the period from week 14 to week 28 of gestation.

Women in the first trimester of pregnancy were excluded because gastrointestinal symptoms, such as nausea, vomiting, dyspepsia, and heartburn, usually encourage them to change their food habits ${ }^{11}$.

A pretested questionnaire was used to collect demographic, socioeconomic, reproductive, and dietary data during individual interviews with the participants. The interviewers were trained dieticians submitted to regular refresher training sessions during the data collection period. Some data were collected from the medical records.

The dependent variables were serum Hemoglobin level $(\mathrm{Hb})$, Hematocrit $(\mathrm{Hct})$, Mean Corpuscular Volume (MCV), and the following markers of iron stores: Serum Iron (Fe), Serum Ferritin (SF), Serum Transferrin (TRF), Total IronBinding Capacity (TIBC), and Transferrin Saturation (TSAT). The iron status of the participants was categorized according to the number of the said markers outside of the recommended ranges: women with an abnormal level of one marker and women with an abnormal level of two or more markers.

The independent variables were age, education level, marital status, per capita household income, gestational age, first prenatal care visit, number of prenatal care visits, parity, abortions, pre-pregnancy weight status, pregnancy weight status, and food intake.

\section{Data collection}

Blood was collected from the participants after a 10-hour fast to determine the levels of anemia and iron store markers. The biochemical tests were performed by the HUJM laboratory. The methods and equipment used for the tests, the cut-off point for each marker, and the classification of the blood markers are listed in Chart 1. 
458 RMS CAMARGO et al.

Chart 1. Reference values and classification of the blood components.

\begin{tabular}{|c|c|c|c|}
\hline Blood components & Analysis method & Cut-off points & Nutritional status classification \\
\hline Hemoglobin & Pentra 80 spectrophotometer, ABX, (Paris, France). & Below $11 \mathrm{~g} / \mathrm{dL}$ & Anemia \\
\hline Hematocrit & $\begin{array}{l}\text { Numeric integration of the mean corpuscular volu- } \\
\text { me. }\end{array}$ & Below 33\% & Anemia \\
\hline Mean Corpuscular Volume & Calculated directly from the red blood cell count. & Below 80fl & Anemia \\
\hline Serum iron & $\begin{array}{l}\text { Automated colorimetric method (BT 3000, Wiener } \\
\text { Lab Group, Argentina). }\end{array}$ & Below $67 \mathrm{mg} / \mathrm{dL}$ & Iron deficiency \\
\hline Serum ferritin & $\begin{array}{l}\text { Chemiluminescence (Modular E170 - ROCHE, } \\
\text { Frankfurt, Germany). }\end{array}$ & Below $22 \mathrm{mg} / \mathrm{dL}$ & Iron deficiency \\
\hline Serum transferrin & $\begin{array}{l}\text { Nephelometry (concentration of an emulsion is } \\
\text { given by comparing its transparency with that of a } \\
\text { standard preparation) (BT 3000, Wiener Lab Group, } \\
\text { Argentina). }\end{array}$ & Above $400 \mathrm{mg} / \mathrm{dL}$ & Iron deficiency \\
\hline Total iron-binding capacity & $\begin{array}{l}\text { Automated colorimetric method (BT 3000, Wiener } \\
\text { Lab Group, Argentina). }\end{array}$ & Above $300 \mathrm{mg} / \mathrm{dL}$ & Iron deficiency \\
\hline Transferrin saturation & $\begin{array}{l}\text { Given by the formula: TSAT }(\%)=\text { serum iron/ } \\
\text { TIBCX } 100 \text {. }\end{array}$ & Below 16\% & Iron deficiency \\
\hline
\end{tabular}

Note: TSAT: Transfmin Saturation; TIBCX: Total Iron Bindeng Capacity.

Weight status before and during pregnancy was classified according to the Body Mass Index (BMI) cut-off points. BMI is given by dividing weight by the square of the height. Weight status before pregnancy was classified according to the Institute of Medicine (IOM) ${ }^{12}$ cut-off points, and weight status during pregnancy was classified according to the cut-offs proposed by the Brazilian Ministry of Health ${ }^{13}$.

A validated Food Frequency Questionnaire (FFQ) developed for the adult population of another city located in the Brazilian Central-West Region ${ }^{14}$ was used for collecting the participants « food intake data because no FFQ validated for the city of Cuiabá (MT) was available at the time. The study FFQ was adapted by excluding some food items and including some dietary iron sources and typical local foods. The original FFQ contained 80 items, and after the adaptation there were 72 items. The FFQ was administered qualitatively, providing seven options for intake frequency: (a) Once daily; (b) two or more times daily; (c) five to six times weekly; (d) Two to four times weekly; (e) once weekly; (f) one to three times monthly; and $(\mathrm{g})$ rarely or never.
For the analysis, the foods were grouped according to their nutritional characteristics, iron bioavailability, and ability to promote iron absorption: iron sources (liver, gizzard, chicken heart, corned beef, beef, and beans), absorption facilitators (orange, acerola berry, lime and cashew apple), and absorption inhibitors (milk, dairy products, soda, tea, and coffee). Therefore, 19 food groups were defined: milk and dairy products, meats and eggs, oils and fats, snacks and canned foods, grains, rice pasta, legumes, non-starchy vegetables, cooked vegetables, tubers and roots, fruits, sugary foods, natural and artificially-flavored juices, tea and coffee, soda, organ meats, iron sources, iron absorption facilitators, iron absorption inhibitors. The reported food intake frequencies were converted into daily frequencies and analyzed as continuous variables. For this purpose, a value of 1 was attributed to foods eaten once daily and the other frequencies were given proportional values, as follows: twice or more daily (2); five to six times weekly $[((5+6) / 2) / 7]=0.79$ times per day; two to four times weekly $[((2+4) / 2) / 7]=0.43$ times per day; once weekly $(1 / 7)=0.14$ times per day; one to three times per month $[((1+3) / 2) / 30]=0.07$ times daily; and rarely or never (0). 


\section{Statistical analyses}

The continuous variables were expressed as means, standard deviations, and 95\% confidence intervals. Proportions were calculated for the categorical variables. The relative anemia frequency was estimated. The frequencies of pregnant women with only one marker of iron stores and those with two or more markers of iron stores at abnormal levels were also calculated.

The normality of the distributions was assessed by the Kolmogorov-Smirnov test, and the means with symmetrical and nonparametric distributions were compared by the Student's $t$ test and Mann-Whitney test, respectively. The categorical variables were compared by the Chisquare test or Fisher's exact test when necessary. The significance level was set at $5 \%$.

\section{R E S U L T S}

A total of 221 pregnant women were eligible for the study. Of these, 36 (16\%) missed the interview and 39 (18\%) did not undergo the biochemical tests. Hence, the final sample consisted of 146 pregnant women, that is, $66 \%$ of the initial sample.

The mean red blood counts and serum iron markers were within the normal levels. The frequency of anemia characterized by abnormal $\mathrm{MCV}, \mathrm{Hb}$, or Hct levels varied from $3 \%$ to $5 \%$.
However, the anemia frequencies characterized by abnormal levels of one or more iron markers were higher, varying from $11 \%$ for transferrin to $39 \%$ for ferritin (Table 1). Only one pregnant woman did not have any abnormal levels of anemia or anemia markers; 38\% $(n=55)$ of the women had one marker at abnormal level, and $62 \%(n=90)$ had two or more markers at abnormal levels (data not shown).

Iron deficiency was not associated with age, education level, income, marital status, parity, and occasion of the first prenatal care visit. Participants who had had miscarriages were more likely to have low serum iron levels $(p=0.03)$ and low TSAT $(p=0.02)$. Women pregnant for more than 20 weeks were more likely to have low ferritin $(p=0.01)$ and high transferrin $(p=0.006)$ levels. Low ferritin level was associated with the number of prenatal care visits: $52 \%$ of the women who had attended at least two prenatal care visits and $24 \%$ of those who attended only one visit had low ferritin levels $(p=0.01)$. Finally, women who were overweight or obese before getting pregnant were also more likely to have low serum iron levels ( $p=0.04$ ) (Table 2 ).

Pregnant women who were overweight or obese $(76 \%)$ before getting pregnant were more likely to have two or more markers of anemia at abnormal levels than those who were underweight $(65 \%)$ or normal weight $(53 \%)$ $(p=0.04)$. There was no association between

Table 1. Markers of serum iron and iron stores in pregnant women seen in public prenatal care facilities of Cuiabá (MT), Brazil, 2009.

\begin{tabular}{llllcc}
\hline Marker & $\mathrm{n}^{*}$ & $\mathrm{M}$ & $\mathrm{SD}$ & $\mathrm{95 \%} \mathrm{Cl}$ & Anemia frequency \\
\hline Hemoglobin $(\mathrm{g} / \mathrm{dL})$ & 146 & 12.1 & 0.74 & $12.0 ; 12.2$ & 5 \\
Hematocrit $(\%)$ & 146 & 36.1 & 2.27 & $35.8 ; 36.5$ & 4 \\
Mean corpuscular volume $(\mathrm{fl})$. & 146 & 89.2 & 4.89 & $88.4 ; 89.9$ & 3 \\
Iron $(\mu \mathrm{g} / \mathrm{L})$ & 143 & 86.0 & 31.5 & $80.7 ; 91.2$ & 30 \\
Serum ferritin $(\mu \mathrm{g} / \mathrm{L})$ & 141 & 39.2 & 36.1 & $33.2 ; 45.2$ & 39 \\
Transferrin $(\mu \mathrm{g} / \mathrm{dL})$ & 133 & 329.3 & 61.4 & $318.7 ; 39.8$ & 11 \\
Transferrin saturation $(\%)$ & 142 & 29.7 & 14.0 & $27.3 ; 32.0$ & 16 \\
Total iron-binding capacity $(\mu \mathrm{g} / \mathrm{dL})$ & 142 & 273.3 & 77.5 & $260.5 ; 286.2$ & 30 \\
\hline
\end{tabular}

Note: M: Mean; SD: Standard Deviation; 95\%Cl: 95\% Confidence Interval.

*The sample size for each marker varied because some biochemical tests were lost. 
460 | RMS CAMARGO et al.

Table 2. Association between socioeconomic and obstetric characteristics and abnormal levels of markers of iron stores in pregnant women ( $n=146$ ) seen at a public prenatal care facility of Cuiabá (MT), Brazil, 2009.

\begin{tabular}{|c|c|c|c|c|c|c|}
\hline \multirow{2}{*}{ Participant characteristics } & \multirow{2}{*}{$\%$} & \multicolumn{5}{|c|}{ Abnormal levels of markers of iron stores ${ }^{1}(\%)$} \\
\hline & & Serum ferritin & Serum iron & Transferrin & TSAT & TIBC \\
\hline \multicolumn{7}{|l|}{ Age (years) } \\
\hline$<25$ & 47 & 21 & 12 & 11 & 7 & 13 \\
\hline$\geq 25$ & 53 & 19 & 19 & 13 & 10 & 17 \\
\hline$p$ value $^{2}$ & & 0.25 & 0.15 & 0.75 & 0.60 & 0.71 \\
\hline \multicolumn{7}{|l|}{ Education level (years) } \\
\hline$\leq 8$ & 36 & 41 & 26 & 11 & 14 & 30 \\
\hline$>8$ & 64 & 40 & 34 & 13 & 19 & 31 \\
\hline$p$ value $^{2}$ & & 0.89 & 0.30 & 0.71 & 0.45 & 0.86 \\
\hline \multicolumn{7}{|c|}{ Per capita household income (minimum salaries) } \\
\hline$\leq 1$ & 60 & 40 & 31 & 12 & 22 & 36 \\
\hline$>1$ & 40 & 41 & 3 & 13 & 9 & 22 \\
\hline$p$ value $^{2}$ & & 0.90 & 0.93 & 0.84 & 0.05 & 0.08 \\
\hline \multicolumn{7}{|l|}{ Marital status } \\
\hline No partner & 19 & 46 & 23 & 4 & 11 & 30 \\
\hline Has partner & 81 & 39 & 33 & 14 & 18 & 30 \\
\hline$p$ value ${ }^{2}$ & & 0.51 & 0.34 & 0.17 & 0.37 & 0.93 \\
\hline \multicolumn{7}{|l|}{ Parity } \\
\hline None & 41 & 37 & 29 & 14 & 14 & 32 \\
\hline One or more & 59 & 43 & 32 & 10 & 19 & 29 \\
\hline$p$ value $^{2}$ & & 0.52 & 0.67 & 0.50 & 0.37 & 0.67 \\
\hline \multicolumn{7}{|l|}{ Miscarriages } \\
\hline Yes & 37 & 45 & 42 & 14 & 26 & 38 \\
\hline No & 63 & 38 & 24 & 11 & 11 & 26 \\
\hline$p$ value $^{2}$ & & 0.36 & 0.03 & 0.58 & 0.02 & 0.13 \\
\hline \multicolumn{7}{|l|}{ Gestational age (weeks) } \\
\hline$<20$ & 57 & 21 & 27 & 3 & 15 & 32 \\
\hline$\geq 20$ & 43 & 56 & 34 & 19 & 18 & 29 \\
\hline$p$ value ${ }^{2}$ & & 0.01 & 0.37 & 0.006 & 0.61 & 0.76 \\
\hline \multicolumn{7}{|c|}{ First prenatal care visit (weeks) } \\
\hline$\leq 12$ & 58 & 46 & 29 & 17 & 16 & 30 \\
\hline$>12$ & 42 & 32 & 34 & 6 & 19 & 31 \\
\hline$p$ value $^{2}$ & & 0.08 & 0.50 & 0.06 & 0.64 & 0.96 \\
\hline \multicolumn{7}{|l|}{ Prenatal care visits } \\
\hline 1 & 42 & 24 & 28 & 7 & 17 & 25 \\
\hline$\geq 2$ & 58 & 52 & 33 & 15 & 17 & 34 \\
\hline$p$ value ${ }^{2}$ & & 0.01 & 0.49 & 0.17 & 0.99 & 0.28 \\
\hline \multicolumn{7}{|l|}{ Pre-pregnancy weight status } \\
\hline Underweight & 21 & 52 & 29 & 10 & 10 & 29 \\
\hline Normal weight & 50 & 34 & 23 & 13 & 15 & 26 \\
\hline Excess weight & 29 & 44 & 45 & 11 & 26 & 38 \\
\hline$p$ value ${ }^{2}$ & & 0.22 & 0.04 & 0.88 & 0.13 & 0.40 \\
\hline \multicolumn{7}{|l|}{ Gestational weight status } \\
\hline Underweight & 21 & 52 & 20 & 7 & 7 & 32 \\
\hline Normal weight & 40 & 35 & 31 & 15 & 16 & 21 \\
\hline Excess weight & 40 & 40 & 36 & 11 & 22 & 38 \\
\hline$p$ value $^{2}$ & & 0.34 & 0.30 & 0.59 & 0.20 & 0.16 \\
\hline
\end{tabular}

Note: ${ }^{1}$ Only one participant had no marker of anemia or iron stores outside the recommended range. ${ }^{2}$ Chi-square test.

TSAT: Transferrin Saturation, TIBC: Total Iron-Binding Capacity. 
Table 3. Weight status and abnormal levels of markers of anemia and iron stores in pregnant women $(n=146)$ seen at a public prenatal care facility of Cuiabá (MT), Brazil, 2009.

\begin{tabular}{|c|c|c|c|c|}
\hline \multirow{2}{*}{ Weight status } & \multirow{2}{*}{ Total $(n=146) \%$} & \multicolumn{3}{|c|}{ Number of markers of anemia/iron stores ${ }^{1}$ at abnormal levels } \\
\hline & & $1(n=55) \%$ & $\geq 2(n=90) \%$ & $p$ value $^{2}$ \\
\hline \multicolumn{5}{|l|}{ Before pregnancy } \\
\hline Underweight & 21 & 35 & 65 & \\
\hline Normal weight & 50 & 47 & 53 & 0.04 \\
\hline Excess weight $^{*}$ & 29 & 24 & 76 & \\
\hline \multicolumn{5}{|c|}{ During pregnancy } \\
\hline Underweight & 20 & 30 & 70 & \\
\hline Normal weight & 40 & 46 & 54 & 0.28 \\
\hline Excess weight & 40 & 35 & 66 & \\
\hline
\end{tabular}

Note: ${ }^{*}$ Partitioned Chi-square test $(p=0.013) .{ }^{1}$ Only one participant had no marker of anemia or iron stores outside the recommended range; ${ }^{2}$ Chi-square test.

Table 4. Daily food group intake frequency according to the number of markers of iron stores at abnormal levels in pregnant women $(n=145)^{*}$ seen at a public prenatal care facility of Cuiabá (MT), Brazil, 2009.

\begin{tabular}{|c|c|c|c|c|}
\hline \multirow{3}{*}{ Food } & \multicolumn{2}{|c|}{$\begin{array}{c}\text { One marker of anemia/iron stores outside } \\
\text { the recommended level }(n=55)\end{array}$} & \multicolumn{2}{|c|}{$\begin{array}{c}\geq 2 \text { markers of anemia/iron stores outside } \\
\text { the recommended level }(n=90)\end{array}$} \\
\hline & \multicolumn{4}{|c|}{ Food group daily intake frequency } \\
\hline & M & $95 \% \mathrm{Cl}$ & M & $95 \% \mathrm{Cl}$ \\
\hline Rice and pasta & 2.0 & $1.9-2.2$ & 2.0 & $1.8-2.1$ \\
\hline Legumes (beans) & 2.4 & $2.0-2.8$ & 2.5 & $2.1-2.9$ \\
\hline Grain-based products (bread, cookies, cakes) & 1.7 & $1.5-1.9$ & 1.9 & $1.7-2.2$ \\
\hline Tubers and roots & 0.6 & $0.4-0.8$ & 0.5 & $0.3-0.6$ \\
\hline Milk and dairy products & 1.5 & $1.2-1.7$ & 1.4 & $1.2-1.6$ \\
\hline Meats and eggs & 2.1 & $1.9-2.4$ & 2.0 & $1.8-2.2$ \\
\hline Organ meats & 0.1 & $0.1-0.2$ & 0.2 & $0.1-0.2$ \\
\hline Non-starchy vegetables & 1.3 & $1.1-1.5$ & 1.2 & $1.0-1.4$ \\
\hline Cooked vegetables & 0.7 & $0.3-1.1$ & 0.5 & $0.4-0.7$ \\
\hline Fruits & 0.7 & $0.5-0.9$ & 0.8 & $0.6-0.9$ \\
\hline Sugary foods & 0.8 & $0.6-1.1$ & 0.7 & $0.6-0.9$ \\
\hline Natural and artificially-flavored juices & 0.9 & $0.7-1.1$ & 1.0 & $0.9-1.2$ \\
\hline Milk and coffee & 0.9 & $0.7-1.2$ & 0.8 & $0.7-0.10$ \\
\hline Soda & 0.5 & $0.3-0.6$ & 0.5 & $0.4-0.7$ \\
\hline Oils and fats & 2.1 & $1.9-2.3$ & 2.1 & $2.0-2.3$ \\
\hline Snacks and canned foods & 1.1 & $0.9-1.3$ & 1.1 & $0.9-1.3$ \\
\hline Iron sources & 2.4 & $2.2-2.6$ & 2.2 & $1.1-2.4$ \\
\hline Iron-absorption inhibitors & 3.2 & $2.8-3.6$ & 3.0 & $2.7-3.3$ \\
\hline Iron-absorption facilitators & 1.1 & $0.8-1.3$ & 1.3 & $1.1-1.5$ \\
\hline
\end{tabular}

Note: M: Mean; 95\%Cl: 95\% Confidence Interval.

* Only one participant had no marker of anemia or iron stores outside the recommended range.

gestational weight status and level of iron stores (Table 3).

Specific food habits were not associated with markers of anemia/ iron stores at abnormal levels (Table 4).
DISCUSSION

Relatively low anemia frequencies were observed in pregnant women on the second trimester of pregnancy seen at a public prenatal 
care service. However, more specific tests showed high frequencies of iron stores. The analyses showed that ferritin was the most sensitive marker of iron stores. The consumption of specific food groups was not associated with low iron stores. Nonetheless, two or more markers of anemia or iron deficiency at abnormal levels were more common in women who were overweight or obese before pregnancy. A history of miscarriages, gestational age, and excess weight before pregnancy were associated with iron stores.

Anemia is detected during pregnancy by measuring $\mathrm{MCV}, \mathrm{Hb}$ and $\mathrm{Hct}$. Serum hemoglobin level is the main parameter routinely used by public prenatal care services for diagnosing anemia $^{15}$. However, the iron stores of pregnant women decrease before their hemoglobin levels do ${ }^{16,17}$. The study results show that anemia may not be detected during prenatal care and that other more effective means of diagnosing iron deficiency anemia should be included in the prenatal care routine.

The main markers of iron stores are ferritin, serum iron level, transferrin, TIBC and TSAT. Serum ferritin level is considered the method of choice for assessing anemia and monitoring its treatment $t^{1,18}$ because of its high sensitivity and relative affordability ${ }^{19}$. On the other hand, serum iron level has small clinical value because of its high variability throughout the day in normal individuals. Transferrin is a plasma protein responsible for iron transport. It holds $0.1 \%$ of the total body iron and also presents important variations during the day ${ }^{18}$. TIBC and TSAT tests complement serum iron test. TSAT corresponds to the amount of iron available for erythropoiesis. When iron stores are low, TSAT level is low ${ }^{20}$ and TIBC level is generally high ${ }^{16}$.

The diagnosis of iron status during pregnancy is also impaired because there is no consensus in the literature regarding which markers best characterize iron deficiency anemia, which is even more critical during pregnancy because of the blood dilution process ${ }^{19}$. These factors make it difficult to compare studies on the prevalence of anemia in pregnant women.

The study results are comparable to those of Karaoglu et al. ${ }^{17}$ who assessed 823 pregnant women in Turkey and found that those with serum $\mathrm{Hb}<11 \mathrm{~g} / \mathrm{dL}$ also had lower serum iron, ferritin and transferrin levels. Additionally, the present findings are similar to those of Dani et al. ${ }^{9}$ regarding the frequency of anemia characterized by low serum ferritin level, which was of $38.2 \%$ in 102 pregnant women receiving prenatal care in public facilities of Rio Grande do Sul, Brazil .

Bressani et al. ${ }^{19}$, on the other hand, found that $45.9 \%$ of 318 pregnant women seen at an outpatient prenatal care clinic of Recife (PE), had anemia, but not anemia characterized by low serum ferritin levels. Serum ferritin level may increase during acute and chronic inflammatory diseases, alcohol abuse, and cancer, conditions which are commonly seen in regions where infectious and parasitic diseases are endemic ${ }^{16}$. These factors may have contributed to the differences found between the results of the present study and those of Bressani et al. ${ }^{19}$.

Although the present study tried to control the effect of gestational age on the biochemical markers by assessing only women on the second trimester of pregnancy (14 to 28 weeks), these markers changed over time, that is, abnormal ferritin or transferrin levels were more common in women pregnant for more than 20 weeks. These results corroborate $\mathrm{Cruz}^{21}$, who found that ferritin levels decrease as gestational age increases.

A study with 772 pregnant women seen at primary health care facilities of the district of Butantã in the city of São Paulo also found a higher prevalence of iron deficiency in women with higher gestational ages, characterized by a decrease in the mean $\mathrm{Hb}$ levels from one trimester of pregnancy to the next ${ }^{22}$. In the said study, the authors emphasized that the main cause for lower hemoglobin levels was blood dilution and pointed out that other markers need to be assessed for 
differential anemia diagnosis, especially MCV and red blood Cell Distribution Width (RDW). RDW is a marker of anisocytosis, an index of Red blood cell size variation ${ }^{22}$. This marker was not assessed by the present study, which may be considered a study limitation given its importance for the assessment of iron status.

Padilha et al. ${ }^{23}$ did not find an association between pre-pregnancy body mass index and anemia during pregnancy. However, in agreement with the present study, the aforementioned authors also observed that the frequency of anemia in women with gestational overweight or obesity increased gradually over time.

The mean daily intake of dietary iron sources by the participants was low. Vasconcelos et al. ${ }^{24}$ showed that pasta, bread, cookies, and cakes were the most common iron-fortified foods consumed by pregnant women seen at the Hospital da Universidade de Brasília, and the frequencies of overweight and obesity among these women were also high. Although wheat flour is considered a good iron vehicle, consumption of fortified foods should be prescribed with caution given the high frequencies of excess weight in pregnant women and the general population. New studies are needed to identify other iron and folic acid vehicles with lower energy densities.

Another limitation of this study is that ferrous sulfate supplementation was not assessed. The study prenatal care service routinely prescribes ferrous sulfate to all pregnant women but the supplement may not be taken correctly. Other data would be necessary to assess the role of ferrous sulfate on the markers of iron status.

The study results allow the identification of pregnant women at greater risk of having low iron stores, even when anemia markers are within the normal ranges. These results are also relevant for the development of routine dietary and nutritional counseling strategies for pregnant women seen at public prenatal care facilities to prevent and treat anemia.

\section{CONCLUSION}

The frequency of anemia characterized by the hemoglobin levels of pregnant women on the second trimester of pregnancy seen at a public prenatal care facility of Cuiabá (MT), was of $5 \%$. However, the frequency of iron deficiency characterized by low serum ferritin level was of $39 \%$. Pregnant women with a history of miscarriages, those at 20 or more weeks of pregnancy, and those who were overweight or obese before pregnancy were more likely to have iron deficiency. Consumption of specific food groups was not associated with anemia.

\section{CONTRIBUTORS}

RMS CAMARGO conceived the study, collected, treated, analyzed, and interpreted the data, and conceived, wrote, and reviewed the manuscript. RA PEREIRA: analyzed and interpreted the data; conceived the manuscript; and reviewed the manuscript. EM YOKOO analyzed and interpreted the data; and reviewed the manuscript. J SCHIRMER: conceived the study; analyzed and interpreted the data; and reviewed the manuscript.

\section{REFERE N CES}

1. World Health Organization. Iron deficiency anaemia: Assessment, prevention, and control: A guide for programme managers. Geneve: WHO; 2001.

2. World Health Organization. Assessing the iron status of populations: Report of a Joint World Health Organization, Centers for Disease Control and Prevention Technical Consultation on the assessment of iron status at the population level. Geneve: WHO; 2004.

3. Kalaivani K. Prevalence and consequences of anaemia in pregnancy. Ind J Med Res. 2009; 130(5): 627-33.

4. Brasil. Ministério da Saúde. Pesquisa nacional de demografia e saúde da criança e da mulher - PNDS 2006: dimensões do processo reprodutivo e da saúde da criança. Brasília: MS; 2009. Capítulo 13: Micronutrientes.

5. Côrtes MH, Vasconcelos IAL, Coitinho DC. Prevalência de anemia ferropriva em gestantes brasileiras: 
uma revisão dos últimos 40 anos. Rev Nutr. 2009; 22(3):1-11. doi: 10.1590/S1415-5273200900030 0011.

6. Vitolo MR, Boscaini C, Bortolini GA. Baixa escolaridade como fator limitante para o combate à anemia entre gestantes. Rev Bras de Ginecol Obstetr. 2006; 28(6):331-9. doi: 10.1590/S0100-72 032006000600003.

7. Baig-Ansari N, Badruddin SH, Karmaliani R, Harris $\mathrm{H}$, Jehan I, Pasha $\mathrm{O}$, et al. Anemia prevalence and risk factors in pregnant women in an urban area of Pakistan. Food Nutr Bull. 2008; 29(2):132-9.

8. Cunningham FG, MacDonald PC, Gant NF, Leveno KJ, Hankins GDV, Clark SL. Obstetrícia. 20ª ed. Rio de Janeiro: Guanabara Koogan; 2000.

9. Dani C, Rossetto S, Castro SM, Wagner SC. Prevalência da anemia e deficiências nutricionais, através de diferentes parâmetros laboratoriais, em mulheres grávidas atendidas em dois serviços de saúde pública no Rio Grande do Sul. Rev Bras Anal Clín. 2008; 40(3):171-5.

10. Leal MC, Gama SGN, Cunha CB. Desigualdades sociodemográficas e suas conseqüências sobre $O$ peso do recém-nascido. Rev Saúde Pública. 2006; 40(3):466-73. doi: 10.1590/S0034-89102006000 300015.

11. Malta MB, Carvalhares MABL, Parada CMGL, Corrente JE. Utilização das recomendações de nutrientes para estimar prevalência de consumo insuficiente das vitaminas $\mathrm{C}$ e $\mathrm{E}$ em gestantes. Rev Bras Epidemiol. 2008; 11(4):573-83. doi: 10.1590/ S1415-790X2008000400006

12. Institute of Medicine. Nutrition during pregnancy. Washington (DC): National Academy Press; 1990.

13. Brasil. Ministério da Saúde. Pré-natal e puerpério: atenção qualificada e humanizada - manual técnico. Brasília: MS; 2005.

14. Ribeiro AR, Sávio KEA, Rodrigues MLCF, Costa THM, Schmitz BAS. Validação de um questionário de freqüência de consumo alimentar para população adulta. Rev Nutr. 2006; 19(5):553-62. doi: 10.1590/\$1 415-52732006000500003.

15. Milman N. Prepartum anaemia: Prevention and treatment. Ann Hematol. 2008; 87:949-59. doi: 10.1007/S00277-0800-0518-4.

16. Ma AG, Schouten EG, Wang Y, Xu RX, Zheng MC, $\mathrm{Li} Y$, et al. Micronutrient status in anemic and non-anemic Chinese women in the third trimester of pregnancy. Asia Pac J Nutr. 2009; 18(1):41-7.

17. Karaoglu L, Pehlivan E, Egri M, Deprem C, Gunes $\mathrm{G}$, Genc MF, et al. The prevalence of nutritional anemia in pregnancy in an East Anatolian province, Turkey. Br Med Cad Public Health. 2010; 10:3291-12. doi: 10.1186/1471-2458-10-329.

18. Nair KM, Bhaskaram P, Balakrishna N, Ravinder P, Sesikeran B. Response of hemoglobin, serum ferritin, and serum transferring receptor during iron supplementation in pregnancy: A prospective study. Nutr Appl Nutr Investig United States. 2004; 20(10):896-9. doi: 10.1016/ j.nut.2004.06.011.

19. Bressani CC, Souza Al, Batista Filho M, Figueiroa JN. Anemia e ferropenia em gestantes: dissensos de resultados de um estudo transversal. Rev Bras Saúde Mater Infant. 2007; 7(Supl 1):15-22. doi: 10.15 90/S1519-38292007000600002.

20. Gabrielloni MC. Estudo da prevalência de anemia e da perda hemática em parto vaginal e cesárea (doutorado). São Paulo: Universidade Federal de São Paulo; 2002.

21. Cruz RD. A avaliação da deficiência de ferro durante o processo gestacional e sua relação com o consumo alimentar e a suplementação com ferro (mestrado). São Paulo: Universidade Federal de São Paulo; 2009.

22. Machado EHS. Anemia em gestantes atendidas em Unidades Básicas de Saúde da região administrativa do Butantã, município de São Paulo, em 2006 e 2008 (doutorado). São Paulo: Universidade Federal de São Paulo; 2011.

23. Padilha PC, Saunders C, Machado RCM, Silva CL, Bull A, Sally EOF, et al. Associação entre o estado nutricional pré-gestacional e a predição do risco de intercorrências gestacionais. Rev Bras Ginecol Obstet. 2007; 29(10):511-8. doi: 10.1590/\$0100-7 2032007001000004.

24. Vasconcelos IAL, Côrtes MH, Coitinho DC. Alimentos sujeitos à fortificação compulsória com ferro: um estudo com gestantes. Rev Nutr. 2008; 21(2): 149-60. doi: 10.1590/S1415-527320080002000 03.

Received on: 18/6/2012

Final version on: 11/3/2013 Approved on: 25/4/2013 